\title{
Exploring EFL Writing Teacher Confidence as A Response to Emergency Remote Teaching: A Preliminary Survey using TPACK Framework
}

\author{
Hanna Sundari', Fakhrurrazi M. Amin 2*, Nur Syamsiah ${ }^{3}$ Anita ${ }^{4}$ \\ ${ }^{1}$ Universitas Indraprasta PGRI, Jakarta Indonesia. E-mail: hanna.sundari@gmail.com \\ 2Institut Agama Islam Negeri (IAIN) Langsa, Indonesia. E-mail: fakhrurrazi.amin@iainlangsa.ac.id \\ ${ }^{3}$ Universitas Raden Intan (UIN) Lampung, Indonesia. E-mail: syamsiahnur13@yahoo.com \\ ${ }^{4}$ Universitas Islam Sultan Maulana Hasanuddin, Banten. Indonesia. E-mail: anita.ftk@uinbanten.ac.id \\ *Corresponding author
}

\section{ARTICLE INFO}

Keywords:

Academic writing; Covid-19 pandemic; EFL writing; Teacher confidence; TPACK framework

How to cite:

Sundari, H., Amin, F. M., Syamsiah, N., Anita, A. (2021). Exploring EFL Writing Teacher Confidence as A Response to Emergency Remote Teaching: A Preliminary Survey using TPACK Framework. Langkawi: Journal of The Association for Arabic and English, 7(2), 145156.

DOI:

http://dx.doi.org/10.31332/lk w.v7i2.2761

\section{History:}

Received: 2021-04-11

Accepted: 2021-12-10

Published: 2021-12-30

\begin{abstract}
Online remote teaching has been implemented to curb the spread of corona virus (Covid-19) pandemic. Due to this unprecedented situation, EFL writing teachers should immediately adjust their teaching approaches through utilizing technology. Given the fact that the utilization of technology is ubiquitous in language teaching, rapid changing into full online teaching certainly brings some adaptations. Teachers have to handle full online learning and apply technology tools they apparently have never used before within a very short time preparation. This current study explored EFL writing teachers' confidence, including their perceptions, in response to emergency remote teaching during Covid-19 pandemic as an initial survey. Twenty-two teachers who teach academic writing courses from nine universities in Indonesia took part in a survey through online questionnaire modified from EFL TPACK assessment by Baser, Kopcha, and Ozden (2016). Descriptive and thematic approaches were used as data analysis. The findings show that the EFL writing teachers' confidence ranged between somewhat confident to fairly confident in the seven areas of technology, content, and pedagogy. They believe that competences they have are sufficient in managing online EFL academic writing course during emergency remote teaching. Nonetheless, when technology is integrated to other areas, the confidence levels seemingly decrease. Awareness of technical material and pedagogic technological knowledge received the lowest scores from all fields. Integration of technology in the process of language teaching, requires teachers to always improve their TPACK abilities through various ways, and this must also be supported by adequate facilities and infrastructure.
\end{abstract}

\section{Introduction}

Recently, the face-to-face teaching mode has been rapidly changed into a full online teaching system. A temporary change in the instructional system is mainly caused by a crisis situation (Hodges et al., 2020). This mode of teaching system requires the use of technology in actions. Some previous studies have proven that technologysupported language learning (Cahyani \& Cahyono, 2012) has been an essential part in educational contexts. In particular, it enhances the perspective of the L2 learning and acquisition process (Chen, 2012), helps language course developers and test makers (Chalhoub-Deville, 2001), and becomes a potential source of language input (Skehan, 
2003). However, as a pedagogical tool, technology uses can be effective and meaningful if teachers have knowledge of the technology itself. Besides, integrating technology into education can be done by identifying teachers' views about the content taught (Anderson et al., 2013). The efficient incorporation of technology relies on the interactions between knowledge of teaching, content, and technology, called Technology Pedagogy and Content Knowledge (TPACK) (Joo et al., 2018) (Angeli \& Valanides, 2009 in Ertmer \& Ottenbreit-Leftwich, 2010). Moreover, integration technology for teaching should be considered, such as time, training, and technical supports as the most persistent barrier. Teachers need sufficient time to discover, assess, and apply the tools and resources of technology; otherwise, they do not take any advantage of it in supporting student learning (Francom, 2020). In spite of it, on the urgent remote teaching during the Covid-19 outbreak, the teachers have to handle full online learning and apply technology tools they apparently have never used before within a very short time preparation.

Knowing how to use technology may enhance the teacher to use it more effectively. However, it is not enough if the teachers are less confident using that knowledge to help students learn (Ertmer \& Ottenbreit-Leftwich, 2010). Teacher confidence is a significant element of teacher professionalism for building professional capital; teachers have to feel confident about what they are capable of and how effect changes in teaching (Nolan \& Molla, 2017). Confidence relates to influencing one's convictions in one's abilities ( $\mathrm{O}^{\prime}$ Neill \& Stephenson, 2012). The attitude of confidence is often rooted in the concept of self-efficacy by Rotter (1966) and Bandura (1977). Based on Rotter's study, teachers with a high degree of effectiveness believed that they could regulate motivation and accomplishment of the students; at an almost similar point, Bandura viewed self-efficacy as one's cognitive process in constructing belief about their capacity to perform specific attainment (Jimenez-Silva et al., 2012). Feelings of self-efficacy can decide whether the behavior will be performed, how much effort there is going to be devoted and how long it is going to be lasted (Vanek et al., 1996). As a result, individuals with a high level of self-confidence in their ability would look at difficult tasks as a challenge rather than a barrier (Bandura, 1994 cited in Willis, Weiser, \& Smith, 2016).

In the context of teaching and technology, confident teachers in integrating technology in their classroom may presumably be a factor in improving instructional practices related to subject content, pedagogy, and technology. Wozney, Venkatesh, and Abrami (2006 cited in Ertmer \& Ottenbreit-Leftwich, 2010) concluded that teacher confidence could be one of the greater predictors of teachers' technology in achieving instructional goals on using technology. Ertmer and Ottenbreit-Leftwich (2010) suggested a number of practices in helping teacher gain their confidence, such as giving teachers time to play with technology, working with competent peers, providing access to appropriate models, and participating in a professional learning community. Related to EFL writing teachers, writing teacher expertise covers context in schooling and socioculture. If teachers move to a different school, or when facing changing student demographics, fresh issues emerging from the reform of education or new teaching situation, their knowledge must be refined or further established(Lee \& Yuan, 2020).

The research in the context of applying technology in emergency remote teaching has been extensively conducted either on teachers' perception and experience 
(Atmojo \& Nugroho, 2020) or students' preferences on digital learning platforms (Amin \& Sundari, 2020). Furthermore, the studies of teacher confidence and technology integration have implied that, for some reasons, even very confident consumers of technology do not always perform considerations for the learning demands (Kessler \& Plakans, 2008). Moreover, learning-focused teachers commonly are confident about mastering the content and teaching the students (Postareff \& Lindblom-Ylänne, 2011). In EFL writing, however, little is known about how confident the EFL teachers are, particularly in teaching writing in university during emergency remote teaching. An insightful seeing about this issue will bring to the deep understanding of EFL writing teachers' efficacy, confidence and teaching performance in managing their writing courses during Covid-19 pandemic from the inside. Therefore, this present study aims to answer the following research question: how confident are the EFL writing teachers in responding to emergency remote teaching in managing their writing courses?

The result of this research informs insights on how confident EFL writing teachers were in handling emergency remote teaching. These may contribute to the EFL writing teacher in preparing and anticipating post-pandemic teaching which requires technological knowledge and competence.

\section{Method}

This preliminary study used a descriptive survey to assess EFL writing teachers' technology competency in teaching writing course during emergency situation or the COVID-19 pandemic. A descriptive survey was carried out to collect information from a group of individuals to explain certain aspects or features (e.g., skills, views, behaviors, opinions, and/or knowledge) by asking questions (Fraenkel et al., 2009). Twenty-two EFL university writing teachers' who teach academic writing courses from nine universities in Indonesia were recruited as participants, with the age range between 27-56 years old. The information about participants' can be seen on Figure1.

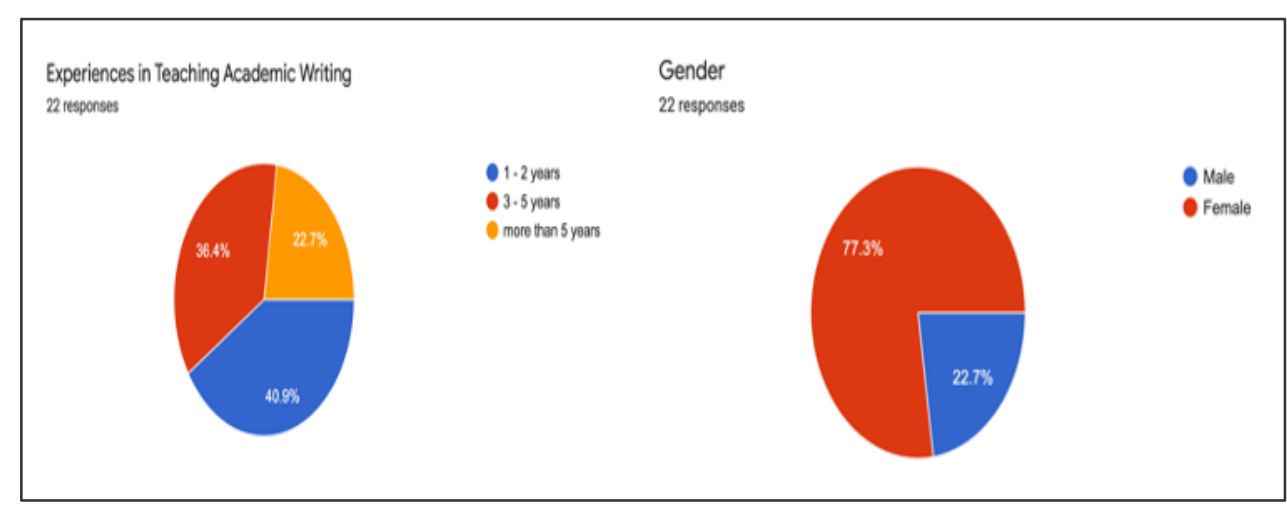

Figure 1. Participants' Gender and Teaching Experiences

In collecting the data, an online questionnaire was designed and modified from TPACK assessment for English as a foreign language called TPACK-EFL Survey items by Baser et al., (2016). It consisted of closed-ended questions with 35 items from 7 constructs, as seen on Table 1. using and 5 scales (not confident at all, slightly confident, somewhat confident, fairly confident, and completely confident). Each construct was led by lead by a question "how confident are that you are able to ..." and followed by a set of statements using action verbs. Moreover, three items of open- 
ended questions were used to discover participants' considerations on selecting and applying technology in assisting teaching. Meanwhile, descriptive and thematic analysis were selected to analyze the gathered data.

Table 1. TPACK-EFL Survey Items modified from Baser et. al., (2016)

\begin{tabular}{lc}
\hline \multicolumn{1}{c}{ Constructs } & Items \\
\hline Technological Knowledge & 6 \\
Content Knowledge & 6 \\
Pedagogical Knowledge & 5 \\
Pedagogical Content Knowledge & 5 \\
Technological Content knowledge & 4 \\
Technological Pedagogical Knowledge & 6 \\
Technological Pedagogical Content & 3 \\
Knowledge $\quad$ & \\
\hline
\end{tabular}

\section{Findings and Discussion}

In managing their writing courses, the majority of participant-teachers applied more than one digital platform for one writing course, only five of them used single platform. They were Google Classroom, Zoom, Google Meet, Google Drive, Dropbox, and Google Form. Moreover, WhatsApp mobile application messenger was mostly used in the EFL writing course.

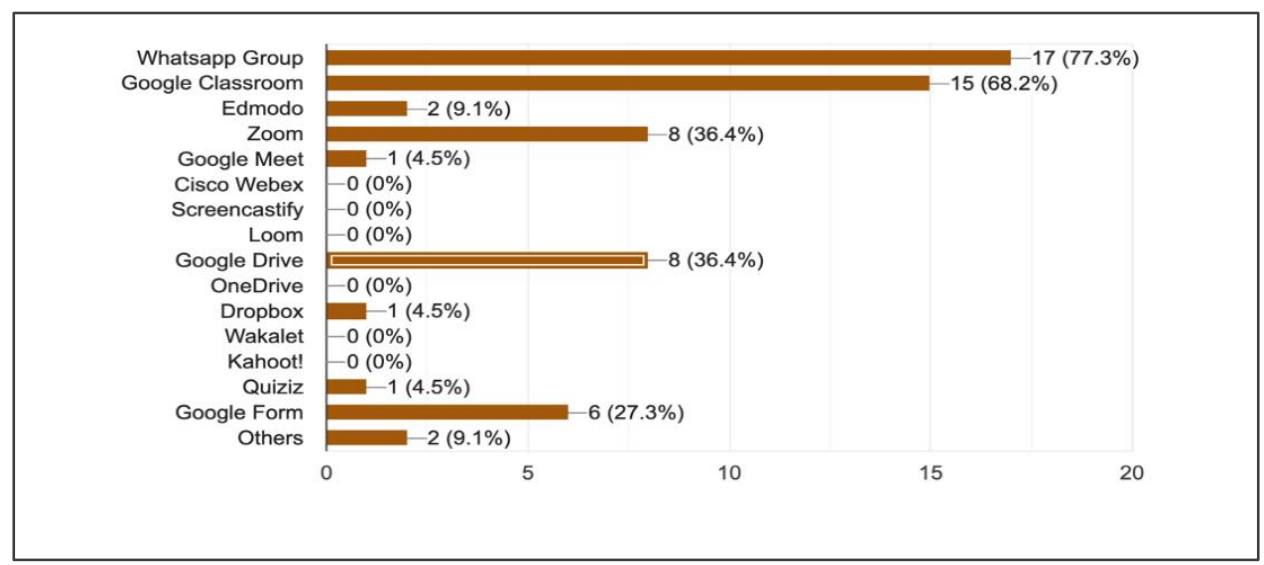

Figure 2. Digital Platforms Used in EFL Writing Courses

In relation to the use of digital platforms, more than half of the participantteachers $(59 \%)$ revealed that it was the first-time experience for them in using the digital platforms for online learning. WhatsApp has probably become a tool for communication and messaging as their daily base, but it was not a pedagogical tool. Moreover, video conferencing platforms such as Zoom or Google Meet never had a place at a face-to-face teaching system. Meanwhile, the rest of the participant-teachers stated that they have been familiar with some digital platforms, such as Google Drive, Edmodo, Google Classroom, Quizizz. They used them to help and assist their activities on face-to-face writing courses.

For technological knowledge, in all statements, the scores were ranged from 3.27 to 4.13 . It indicates that the EFL writing teachers' levels of confidence in operating and controlling the platforms and the computer system, in general, were somewhat confident to fairly confident. The highest level was on understanding technological 
terms on the platforms they used. On the other hand, handling troubleshoots on the computer or technical problems received the lowest score, as seen in Table 2.

Table 2. The Teachers' Scores on Technological Knowledge, Content Knowledge, and Pedagogical Knowledge

\begin{tabular}{|c|c|c|}
\hline \multicolumn{3}{|c|}{$\begin{array}{ll}\text { No. } & \text { Statements } \\
\text { Technological Knowledge } & \end{array}$} \\
\hline 1. & $\begin{array}{l}\text { Understand technological terms on platform/application } \\
\text { you use appropriately? }\end{array}$ & 4.13 \\
\hline 2. & $\begin{array}{l}\text { Adjust computer setting (installing software and } \\
\text { establishing connection)? }\end{array}$ & 3.90 \\
\hline 3. & Use computer peripheral (printer, headphone, scanner)? & 4.09 \\
\hline 4. & Troubleshoot the computer problems independently? & 3.27 \\
\hline 5. & $\begin{array}{l}\text { Use the platform/application you choose for writing } \\
\text { class? }\end{array}$ & 4.00 \\
\hline 6. & $\begin{array}{l}\text { Operate all the features offered on the } \\
\text { platform/application you use? }\end{array}$ & 4.00 \\
\hline \multicolumn{3}{|c|}{ Content Knowledge } \\
\hline 1. & Understand parts of the essay? & 4.40 \\
\hline 2. & $\begin{array}{l}\text { Understand writing process approach in developing } \\
\text { essay? }\end{array}$ & 4.40 \\
\hline 3. & Understand types of essays (process, cause/effect, etc.)? & 4.31 \\
\hline 4. & Understand paraphrasing and summarizing? & 4.40 \\
\hline 5. & Understanding quotation and plagiarism? & 4.40 \\
\hline 6. & Understand how to write an article for journal? & 4.31 \\
\hline \multicolumn{3}{|c|}{ Pedagogical Knowledge } \\
\hline 1. & $\begin{array}{l}\text { Use teaching methods and techniques that are appropriate } \\
\text { for learning environment? }\end{array}$ & 4.04 \\
\hline 2. & $\begin{array}{l}\text { Design a learning experience that is appropriate to the } \\
\text { level of the students? }\end{array}$ & 4.00 \\
\hline 3. & $\begin{array}{l}\text { support students' learning in accordance with physical, } \\
\text { mental, emotional, social and cultural differences? }\end{array}$ & 4.00 \\
\hline & $\begin{array}{l}\text { reflect the experiences I gain from professional } \\
\text { development programs to your teaching process? }\end{array}$ & 4.09 \\
\hline 5. & $\begin{array}{l}\text { support students' out-of-class work to facilitate their self- } \\
\text { regulated learning? }\end{array}$ & 3.90 \\
\hline
\end{tabular}

In an EFL writing context, content knowledge was dealt with the subjectcontent generally taught in academic writing courses, such as paragraph/essay development of certain academic genre types and writing a research paper for journal. Here, the participant-teachers believed they were fairly confident in understanding those items, with scores ranging from 4.31 to 4.40 as in Table 1 . In the area of pedagogical knowledge, most participant-teachers responded that they were fairly confident in their pedagogical competence, such as using teaching methods/techniques, designing learning activity, supporting students' learning, and reflecting what have they experience in classroom practices. However, supporting students to be independent learners gained the lowest score of all (see Table 1). They 
probably assumed that they are less confident in facilitating students' self-regulated learning through online learning compared to other pedagogical items.

Moreover, in the area of pedagogical content knowledge, the participantteachers were asked to respond on five statements. The scores were ranged between 3.86 to 4.13 , see Table 3. It shows that the EFL writing teachers' confidence level was somewhat confident to fairly confident. The lowest levels were on managing effective learning and evaluating students' progress on writing. Then, they reported fairly confident in selecting approaches/methods, preparing learning activities, and adapting a lesson plan for appropriate and effective writing courses.

Table 3. The Teachers' Scores on Pedagogical Content Knowledge

\begin{tabular}{llc}
\hline No. & \multicolumn{1}{c}{ Statements } & Scores \\
\hline 1. & manage an effective learning environment for writing? & 3.90 \\
2. & evaluate the students' learning progress of writing? & 3.86 \\
3. & $\begin{array}{l}\text { use appropriate teaching approach and methods for } \\
\text { writing skill to support students' writing development? }\end{array}$ & 4.00 \\
4. $\quad \begin{array}{l}\text { prepare curricular activities that develop students' writing } \\
\text { skill? }\end{array}$ & 4.00 \\
5. $\quad \begin{array}{l}\text { adapt a lesson plan in accordance with students' writing } \\
\text { skill? }\end{array}$ & 4.13 \\
\hline
\end{tabular}

Table 4. The Teachers' Scores on Technological Content Knowledge

\begin{tabular}{|c|c|c|}
\hline No. & Statements & Scores \\
\hline \multicolumn{3}{|c|}{ Technological Content Knowledge } \\
\hline 1. & $\begin{array}{l}\text { take advantages of the platform/application to express } \\
\text { ideas for teaching writing? }\end{array}$ & 3.77 \\
\hline 2. & $\begin{array}{l}\text { use the platform/application to enhance students' writing } \\
\text { skill in essay development? }\end{array}$ & 3.63 \\
\hline 3. & $\begin{array}{l}\text { use the platform/application to stimulate students' } \\
\text { writing skill in writing an article? }\end{array}$ & 3.63 \\
\hline 4. & $\begin{array}{l}\text { use the platform/application that allows the student to } \\
\text { write using process writing? }\end{array}$ & 3.77 \\
\hline \multicolumn{3}{|c|}{ Technological Pedagogical Knowledge } \\
\hline & $\begin{array}{l}\text { meet the students' learning need by using the } \\
\text { platform/application you choose? }\end{array}$ & 3.54 \\
\hline 2. & $\begin{array}{l}\text { support the students to use the platform/application to } \\
\text { improve their higher order thinking skill? }\end{array}$ & 3.68 \\
\hline 3. & $\begin{array}{l}\text { manage an effective learning environment to learn writing } \\
\text { while using the platform/application? }\end{array}$ & 3.81 \\
\hline 4. & $\begin{array}{l}\text { achieve the learning goals on syllabus by using the } \\
\text { platform/application? }\end{array}$ & 3.81 \\
\hline 5. & $\begin{array}{l}\text { design learning materials and media to improve students' } \\
\text { writing skill by using the platform/application? }\end{array}$ & 3.95 \\
\hline & $\begin{array}{l}\text { develop assessment for writing skill using the } \\
\text { platform/application? }\end{array}$ & 3.77 \\
\hline
\end{tabular}


For technological content knowledge, the participant-teachers felt somewhat confident on all items given. They were seemingly not certain about their ability to use the platforms/application to enhance and stimulate students' writing skills in essay development and composing an article. Meanwhile, on technology pedagogical knowledge, the scores were ranged between 3.54 to 3.95. The participant-teachers thought that they were somewhat confident in all items given. The lowest level was on the learning meets. The participant-teacher found they were less confident that using the platform/application and online learning in general would meet the students' learning needs. Additionally, they were fairly confident in designing learning media and materials for the online writing course (see Table 4.)

Technological pedagogical content knowledge integrates the ability or competence of using technology, principles in pedagogy, and content in writing courses. The participant-teachers felt generally somewhat confident on the items given. They were not fully confident that they can use the digital platform to develop students' writing skill and assist them in using the platforms independently. Conversely, the participant-teachers were, compared to other statements, more confident that they can enhance their professional development in teaching writing by using technology (see Table 5).

Table 5. The Teachers' Scores on Technological Pedagogical Content Knowledge

\begin{tabular}{llc}
\hline No. & \multicolumn{1}{c}{ Statements } & Scores \\
\hline 1. & $\begin{array}{l}\text { use the platform/application to develop students' writing } \\
\text { skill? }\end{array}$ & 3.86 \\
2. & $\begin{array}{l}\text { support the students to use the platform/application to } \\
\text { improve their writing skill in independent manner? }\end{array}$ & 3.81 \\
3. $\quad \begin{array}{l}\text { support your professional development by using the } \\
\text { technological tools and resources to continuously improve } \\
\text { the teaching writing process? }\end{array}$ & 3.95 \\
\hline
\end{tabular}

Table 6. The Summary Scores of TPACK EFL Items

\begin{tabular}{ll}
\hline Items & Scores \\
\hline Technological knowledge & 3.90 \\
Content Knowledge & 4.37 \\
Pedagogical Knowledge & 4.01 \\
Pedagogical Content Knowledge & 3.98 \\
Technological Content knowledge & 3.70 \\
Technological Pedagogical Knowledge & 3.76 \\
Technological Pedagogical Content & 3.87 \\
Knowledge & \\
\hline
\end{tabular}

Table 6 shows the summary scores of seven areas. There were ranged between 3.70 to 4.37 . The highest score was on the area of content knowledge, with 4.37. It indicates that the EFL writing teachers on this study felt they are fairly confident on the content knowledge. They believe that they have sufficient knowledge on writing content, such as paragraph/essay development, writing article for publication and other academic genre types. The next areas were pedagogical knowledge, pedagogical 
content knowledge, and technological knowledge with the scores 4.01, 3.98, 3.90, respectively. The last three scores were 3.87 for technological pedagogical content knowledge, 3.76 for technological pedagogical knowledge, and 3.70 for technological content knowledge.

Overall, the participant-teachers' confidence tends to somewhat confident to fairly confident on seven areas of TPACK given. However, the scores decreased when it came to integration of the areas. The participant-teachers had lesser confidence as they need to combine content of writing and/or pedagogical competence they had with the use of technology. They were seemingly uncertain on their ability to integrate several areas in one teaching-learning session. They felt not quite sure whether they were able to combine pedagogical practice, writing content, and technology during the emergency remote teaching, considering that it was mostly the first-time experience for them in using the technology tools as pedagogical tools.

On open-ended questions, participant-teachers were also revealed their opinions about teachers' competence and considerations when conducting technology in online learning. The following are the excerpts from the teachers' responses:

"In my opinion the writing teacher should have a competence in technology especially on how to use and operate computer and application to design learning materials and media for making her easier in applying the online learning system. The teacher also can make an innovation through designing learning materials and develop assessment in delivering the material." (T7)

"Based on my experiences when applying technology-assisted teaching writing, some important things should be considered by lecturers are getting ready to adapt with technological learning, through attending webinar dealing with technology in teaching and learning especially Academic Writing during distance learning, and sharing knowledge with other lecturers who expert in writing technology tools. Besides, financial aspect is also important to support the sophisticated technology to purchase some devices such as (laptop/netbook and mobile phone) and its access (internet quota)." (T5)

The participant-teachers revealed that their confidence levels on managing EFL writing courses during the emergency remote teaching were between somewhat confident and fairly confident. They believed that they had sufficient competence in writing content, pedagogy and technology in managing writing courses. Nonetheless, the levels of confidence became slightly smaller in amount when handling and integrating technology. Moreover, considerations need to be taken place in online learning; one of them was the teacher's technological competence. The expansion of technology in education has resulted in opportunities for learning where teachers can access learning through online programs (Niess, 2011). However, bringing technology into the classroom may require a lot of things to consider. Not only educational and technological aspects, the teachers' competence and confidence in applying the technology tools should be emphasized. The teacher confidence can be one of the greater indicator of achievement in instructional goals using technology (Ertmer \& Ottenbreit-Leftwich, 2010). This present study aims to describe how confident EFL writing teachers are in teaching academic writing courses as the rapid change of the teaching system from face-to-face into online learning occurred on emergency remote 
instruction. The level of confidence covers the areas of content, pedagogy, and technology.

In a TPACK framework, technological knowledge is defined as awareness about how new technologies can be used (Cox \& Graham, 2009). It refers to the experience of traditional and modern technology by teachers which is utilized in teaching and also facilitates learning among students (Koehler et al., 2014 cited by Elas, Majid, \& Narasuman, 2019). The university writing teachers on this study revealed that they were somewhat confident to fairly confident. They are quite confident on understanding technological terms, although they are uncertain in handling technical problems when using video conferencing or learning management systems. The finding was similar to the study by Ekrem and Recep (2014). They found that preservice EFL teachers believed that their ability to solve hardware-related technological problems needs improvement.

In the area content knowledge, the participant-teachers felt fairly confident in understanding the content on academic writing courses as well as their pedagogical knowledge. However, they were less confident in supporting the students' selfregulated learning during online learning. Supporting self-regulation learning in online learning is crucial. Using this system, decisions should be taken by students on what to study and how to approach the study materials because the teacher presence is relatively low (Wong et al., 2019). Particularly in asynchronous learning mode, the teachers could not answer the questions and give feedback every time the students access the materials and need help. Less interaction in online learning was also revealed in the study by $\mathrm{Wu}$ and Wang (2015). Despite the fact that the purposes of the technology use are to display information, manage instruction and learn subjectmaterial, none of the purposes encouraged interaction among students, enhanced student cooperation, and stimulated student activity.

Furthermore, the participant-teachers in this study felt somewhat confident to fairly confident about their ability and competence in pedagogical and content knowledge. However, they were slightly less confident when integrating technology, content, and pedagogy for writing courses. They were less confident that using the platform/application and online learning in general meet the students' learning needs.They felt doubt that they are able to use the digital platform to develop students' writing skill and assist them independently. A similar view also came from the writing teachers for nursing students on the research by Tai, Pan, and Lee (2015). They said it was difficult to incorporate peer review practices and provide input on time through online English writing course.

In general, the participant-teachers believed that they were fairly confident on managing online EFL writing courses during emergency remote teaching in all areas of pedagogy, content, and technology. However, the integration between them reduces the teachers' level confidence. The lowest level was technological content knowledge. Similarly, Ekrem and Recep (2014) concluded that the pre-service EFL teacher-participants thought their ability to create a learning environment to build students' new knowledge and skills is at a high level, and technological knowledge and technological content knowledge received the lowest levels. It indicates that though the teachers found they had adequate and sufficient knowledge for teaching, technological competence still becomes a critical issue to overcome. In fact, the most 
persistent barrier in technology integration is time as the teachers need time for transformative ways to test out the technology tools and resources (Francom, 2020).

Contrary to the finding of previous study related to integrating technology into education, it was reported that teachers do not take any advantages of it in supporting student learning since it needs sufficient time to discover, asses, and apply the tools and resources of technology (Francom, 2020). The finding of the current study demonstrated that the participant-teachers felt relatively confident that the use of technology help them improve their professional development as teachers. This is consistent with Wichadee (2011) view that technology becomes inseparable in language teaching learning. It is one of the contents in the growth of language teachers to achieve the aim of effective language teaching. Besides, TPACK significantly affected teacher self-efficacy and perceived ease of using technology (Joo, Park, and Lim 2018). The rapid change of the teaching system onto online learning can potentially stimulate teacher development, particularly in technology. Nonetheless, technological competence and effective technology integration in language teaching do not happen in one day and one night. They come with barriers, such as time, training and technical support, access, teacher belief/motivation, and other factors (Francom, 2020).

Technology integration in language teaching, requires teachers to always improve their TPACK abilities through various ways, both in the form of joint and personal training. However, this must also be supported by adequate facilities and infrastructure.

\section{Conclusion}

The EFL writing teachers' confidence was relatively confident, ranging between somewhat confident to fairly confident. It indicates that they believe their ability and competence are adequate and sufficient in managing online EFL academic writing courses at the university level during emergency remote teaching in the seven areas of technology, content, and pedagogy. However, the levels are seemingly decreasing when integrating technology into the course. Technological content knowledge and technological pedagogical knowledge received the lowest scores from all fields.

This latest research had a limitation with relation to several aspects. The small number of participants may increase the limited information. Therefore, the greater scale of participants needs to take place to look at a wider view, particularly concerning what and how to integrate technology, content, and pedagogy for EFL academic writing courses and its effects on students' academic writing skills. Multiple instruments were highly recommended to obtain a deeper understanding of the issue, such as interviews and observation when teachers and students are on the sessions.

\section{References}

Amin, F. M., \& Sundari, H. (2020). EFL students' preferences on digital platforms during emergency remote teaching: Video conference, lms, or messenger application? Studies in English Language and Education, 7(2). https://doi.org/10.24815/siele.v7i2.16929

Anderson, A., Barham, N., \& Northcote, M. (2013). Using the TPACK framework to unite disciplines in online learning. Australasian Journal of Educational Technology, 29(4), 549-565. https:/ / doi.org/10.14742/ajet.24

Atmojo, A. E. P., \& Nugroho, A. (2020). EFL classes must go online! Teaching activities and challenges during COVID-19 pandemic in Indonesia. Register Journal, 13(1), 
Hanna Sundari, Fakhrurrazi M. Amin, Nur syamsiah, Anita: Exploring EFL Writing Teacher Confidence as A Response to Emergency Remote Teaching: A Preliminary Survey using TPACK Framework

49-76. https:// doi.org/10.18326/rgt.v13i1.49-76

Baser, D., Kopcha, T. J., \& Ozden, M. Y. (2016). Developing a technological pedagogical content knowledge (TPACK) assessment for preservice teachers learning to teach English as a foreign language. Computer Assisted Language Learning, 29(4), 749-764. https://doi.org/10.1080/09588221.2015.1047456

Cahyani, H., \& Cahyono, B. Y. (2012). Teachers' attitudes and technology Use in Indonesian EFL Classrooms. TEFLIN Journal, 23(2), 130-148. https://doi.org/10.15639/teflinjournal.v23i2/130-148

Chalhoub-Deville, M. (2001). Language testing and technology: Past and future. Language Learning and Technology, 5(2), 95-98.

Chen, C.-L. A. (2012). Extended implications of technology in second language teaching and learning. Teachers College, Columbia University Working Papers in TESOL E Applied Linguistics, 11(2), 27-28.

Cox, S., \& Graham, C. R. (2009). Diagramming TPACK in practice: Using an elaborated model of the tpack framework to analyze and depict teacher knowledge. TechTrends, 53(5), 60-69. https://doi.org/10.1007/s11528-009-0327-1

Ekrem, S., \& Recep, C. (2014). Examining preservice EFL teachers' TPACK competencies in Turkey. Journal of Educators Online, 11(2), 1-22.

Elas, N. I. B., Majid, F. B. A., \& Narasuman, S. Al. (2019). Development of Technological Pedagogical Content Knowledge (TPACK) for English teachers: The validity and reliability. International Journal of Emerging Technologies in Learning, 14(20), 18-33. https://doi.org/10.3991/ijet.v14i20.11456

Ertmer, P. A., \& Ottenbreit-Leftwich, A. T. (2010). Teacher technology change: How knowledge, confidence, beliefs, and culture intersect. Journal of Research on Technology in Education, 42(3), 255-284. https://doi.org/10.1080/15391523.2010.10782551

Fraenkel, J. R., \& Wallen, N. E. (2009). How to design and evaluate research in education (seventh). McGraw-Hill Higher Education. https://doi.org/10.1017/CBO9781107415324.004

Fraenkel, J. R., Wallen, N. E., \& Hyun, H. H. (2009). How to desing and evaluate research in education. In Mc Graw Hill (Vol. 4, Issue 3). http://marefateadyan.nashriyat.ir/node/150

Francom, G. M. (2020). Barriers to technology integration: A time-series survey study. Journal of Research on Technology in Education, 52(1), 1-16. https://doi.org/10.1080/15391523.2019.1679055

Hodges, C., Moore, S., Lockee, B., Trust, T., \& Bond, A. (2020). The difference between emergency remote teaching and online learning. Educause Review, 7.

Jimenez-Silva, M., Olson, K., \& Jimenez Hernandez, N. (2012). The confidence to teach english language learners: Exploring coursework's role in developing preservice teachers' efficacy. Teacher Educator, 47(1), 9-28. https://doi.org/10.1080/08878730.2011.632471

Joo, Y. J., Park, S., \& Lim, E. (2018). Factors influencing preservice teachers' intention to use technology. Journal of Educational Technology $\mathcal{E}$ Society, 21(3), 48-59. http://www.jstor.org/stable/26458506

Kessler, G., \& Plakans, L. (2008). Does teachers' confidence with CALL equal innovative and integrated use? Computer Assisted Language Learning, 21(3), 269- 
282. https:// doi.org/10.1080/09588220802090303

Lee, I., \& Yuan, R. (Eric). (2020). Understanding L2 writing teacher expertise. Journal of Second Language Writing, January, 1-12. https://doi.org/10.1016/j.jslw.2020.100755

Niess, M. L. (2011). Investigating TPACK: Knowledge growth in teaching with technology. Journal of Educational Computing Research, 44(3), 299-317. https://doi.org/10.2190/EC.44.3.c

Nolan, A., \& Molla, T. (2017). Teacher confidence and professional capital. Teaching and Teacher Education, 62, 10-18.

O'Neill, S., \& Stephenson, J. (2012). Does classroom management coursework influence pre-service teachers' perceived preparedness or confidence? Teaching and Teacher Education, 28(8), 1131-1143. https://doi.org/10.1016/j.tate.2012.06.008

Postareff, L., \& Lindblom-Ylänne, S. (2011). Emotions and confidence within teaching in higher education. Studies in Higher Education, 36(7), 799-813. https:// doi.org/10.1080/03075079.2010.483279

Skehan, P. (2003). Computer assisted language learning focus on form, tasks, and technology focus on form, tasks, and technology. Computer Assisted Language Learning, 16(5), 391-411. https://doi.org/10.1076/call.16.5.391.29489

Tai, H. C., Pan, M. Y., \& Lee, B. O. (2015). Applying technological Pedagogical and Content Knowledge (TPACK) model to develop an online English writing course for nursing students. Nurse Education Today, 35(6), 782-788. https://doi.org/10.1016/j.nedt.2015.02.016

Vanek, E. P., Snyder, C. W., Hull, A. L., \& Hekelman, F. P. (1996). The relationship between teachers' confidence and use of clinical teaching skills in ambulatory care settings. Teaching and Learning in Medicine, 8(3), 137-141. https://doi.org/10.1080/10401339609539783

Wichadee, S. (2011). Professional development: A path to success for EFL teachers. Contemporary Issues in Education Research, 4(5), 13-22.

Willis, J., Weiser, B., \& Smith, D. (2016). Increasing teacher confidence in teaching and technology use through vicarious experiences within an environmental education context. Applied Environmental Education and Communication, 15(3), 199-213. https://doi.org/10.1080/1533015X.2016.1181013

Wong, J., Baars, M., Davis, D., Van Der Zee, T., Houben, G. J., \& Paas, F. (2019). Supporting self-regulated learning in online learning environments and MOOCs: A systematic review. International Journal of Human-Computer Interaction, 35(4-5), 356-373. https://doi.org/10.1080/10447318.2018.1543084

Wu, Y. T., \& Wang, A. Y. (2015). Technological, pedagogical, and cContent knowledge in teaching English as a foreign language: Representation of primary teachers of English in Taiwan. Asia-Pacific Education Researcher, 24(3), 525-533. https://doi.org/10.1007/s40299-015-0240-7. 